\title{
A Critical Study of "Use alone": Usefulness and Revision in George Herbert's "The Temple."
}

\author{
Dr. Veena R. Ilame
}

Assistant Professor, Department of English, A.G. College, Nagpur, Maharashtra, India

\begin{abstract}
This Research paper argues that it can be seen that Herbert as anxious concerning the approach of shaping the best self; the ideal, useful self, and this unattainable goal drives him, even as he was conscious of and utters in his poetics so that paradoxically he is typical already the best self in his perfect state through God's grace. It is this that it has been proposed that the conversation regarding Herbert's poetry should be revised for acknowledging his commitment to defining the contours of acceptable usefulness and productivity. By examining the structure of heart, the place of poetry and the role of work.
\end{abstract}

Keywords-approach, Herbert, God, Grace, perfect, self.

\section{INTRODUCTION}

Izaak Walton's The Life of George Herbert (1670) includes the story of Herbert's deathbed instructions concerning the handling of his poetic works. Herbert tells Mr Duncon:

Sir, I pray to deliver this little book to my dear brother Ferrar, and tell him he shall find in it a picture of the many spiritual conflicts that have passed betwixt God and my soul before I could subject mine to the will of Jesus my Master; in whose service I have now found perfect freedom; desire him to read it; and then, if he can think it may turn to the advantage of any dejected poor soul, let it be made public; if not, let him burn it; for I and it are less than the least of God's mercies. ${ }^{1}$

This incident identifies a tension between public and private work that informs Herbert's intense interest in the use of his poetry for the aid of others. In "The Churchporch," he begins by justifying his role as "Verser" because "A verse may find him, whom a sermon flies" (1. 4). ${ }^{2}$ Given this uniquely persuasive quality of the verse and Herbert's ongoing desire to help others, I will argue that the need to be useful drives Herbert's poetic endeavours and process of revision. For Herbert, the desire to be useful, to write a book that could "turn to the advantage of any dejected poor soul," is doubly heard; it is a plea to be actively useful - to others, to God, to himself - and it is also an utterance describing a passive state of being use-full, ${ }^{3}$ a state in which there is no space for anything but use. While it is possible to be a poet, preacher, publican, and so on, while also being useful, it is also possible to inhabit one of those roles without being useful. To be use-full reverses the identificatory labels, placing one's position secondary to one's condition as used, a paradoxical state similar to the sacrificed Christ who at the moment of the crucifixion when most passively used was also the most actively useful to humanity. While this distinction seems insignificant at first, Herbert's concerns regarding usefulness and productivity seep into every aspect of critical discussion concerning his poetry because his ideas about usefulness instantiate a type of self that is inextricably bound to Protestant theology's view of grace and works. ${ }^{4}$

Martin Luther's "Preface to the Romans" unites works and faith even while asserting that works can in no way merit salvation: "Hence, the man of faith, without being driven, willingly and gladly seeks to do good for everyone, serve everyone, suffer all kinds of hardships, for the sake of the love and glory of the God who has shown him such grace. It is impossible, indeed, to separate works from faith." ${ }^{5}$ For Luther, then, works naturally arise as a result of receiving God's grace, but these works in no way merit that grace. However, "the search for visible proofs of election" often leads to "doctrine of works" ${ }^{6}$ because proof or evidence can be read as both resulting from grace or as working in the same manner as the fallacy post hoc ergo propter hoc. In other words, good works occurred, and (presumably) salvation occurred; therefore, good works caused salvation.

While this subtle reversal appears consistent with Luther's point that good works follow from faith (since good works happen either way) it threatens to undermine the entire notion of salvation by grace. Hence, good works - which 
are measured by their usefulness and come from a productive person - may be a site of both assurance and anxiety for the believer who may ask him or herself if the works are genuine products of grace or subconsciously motivated efforts to win salvation. ${ }^{7}$ For Herbert, his works of preaching and poetry occupy a similarly vexed position because he believed in salvation by grace.

Critics have focused on this vexed position in discussing the self and its agency in Herbert's poetry. Richard Strier's focus on the heart, which will be centrally important in my argument later, emphasizes feeling and experiences that result because "the work of the Spirit is to apply the Word to the heart." ${ }^{8}$ In that process, the heart changes; a different self emerges, a self who works to align with the Word through being useful and productive like the Spirit. I propose that we revise the conversation about Herbert's poetry to acknowledge his commitment to defining the contours of acceptable usefulness and productivity. By examining the structure of the heart, the place of poetry, and the role of work, I argue that we see Herbert as anxious about how to shape the best self: the ideal, useful self. This unattainable goal drives him, even as he knows and utters in his poetry so that paradoxically he is always already the best self in his (im) perfect state through God's grace. Herbert shapes and revises the self through revising his texts, an ongoing process lasting until his death. By changing, deleting, and adding poems, Herbert enacts and experiences re-vision. He sees things again, from an altered perspective, and in those moments of viewing again, he struggles to be both useful and use-full, actively productive and passively used.

\section{THE STRUCTURE OF THE HEART}

For Herbert, the central anxiety overworks derives from the potentially dual origin of works as either naturally arising from a state of grace or from an assertive self that directs attention away from God. ${ }^{9}$ The tension between actual usefulness as expressed through works and being passively used - a state Luther defines as to "suffer another to work in us, that is to say, God" 10 - binds one in a paralyzing state of introspection. To evaluate works does not require an external perspective that can judge something as useful; instead, this evaluative paradigm demands the reorientation of perspective to an internal analysis of the heart's status. The heart functions as a synecdoche of the self for Herbert and the status of the heart occupies a prominent place in many of the poems in The Temple. I will argue that the passive state of being usefull is fleeting. Only in glimpses does Herbert view what it means to be fully used by God's grace; simultaneously, being fully used is a prerequisite to evaluating the active expression of usefulness in one's works. Hence, this ongoing anxiety both charges the reworking and creation of poems and also leads to new conceptions of the heart the self - in moments of revision wherein the self's understanding shifts. For Herbert, these moments of aligning the desired (use-full) self with the actual (useful) self are inevitably followed by a realization of imperfection. That realization results in the experience of profound lack, driving a revisionary process to approximate that previous alignment.

When it comes to the matter of the heart, Herbert begins "The Church" by placing this struggle in the foreground in "The Altar." Despite being one of Herbert's most frequently analyzed poems, a consensus on the "The Altar" continues to elude critics. Stanley Fish holds by far the most radical view. He argues that the poem and the poet are undone "because its true artificer is God." ${ }^{11}$ In Fish's account, "The Altar" perfectly exemplifies the dissolution of the self. Barbara Lewalski, on the other hand, sees this poem as an example of a love relationship between servant and Lord. More specifically in terms of Fish's claim, Lewalski says that this moment is actually "most important to the speaker's self-definition." 12 Michael Schoenfeldt also focuses on the self in this poem, but he sees neither dissolution nor exaltation; instead, Schoenfeldt sees "The Altar" as aggravating the "dispute between divine and human agency, ... . exposing the tension at the heart of all devotional effort between the finely wrought work of submission and the self-immolation that submission intends to induce." 13

These critics represent only a sampling of positions regarding "The Altar," but I select them to highlight because all of them agree on the importance of the self and the relationship between the self and God. I agree that the dynamic of the self and God configures the shape and narrative structure of the poem, but I propose that we reframe this dynamic to consider the issue of usefulness. As a result of this reorientation, we can see "The Altar" as staging the experience of being use-full in the process of God's internal work on the heart and the effect that state of grace has on the poet's active usefulness exhibited through praising God's creative craft with a lesser version of that same craft. To begin, however, it will help to look at the poem. Of course, the first thing to notice about the poem is its shape. As Strier notes, "It is . . . a perfectly shaped classical altar." 14

A broken A L T A R, Lord, thy servant rears, Made of a heart, and cemented with teares: 
Whose parts are as thy hand did frame; No workman's tool hath touch'd the same.

\section{A H E A R T alone}

Is such a stone,

As nothing but

Thy power doth cut. Wherefore each part

Of my hard heart

Meets in this frame,

\section{USEFULNESS AND REVISION IN THE TEMPLE}

To praise thy Name:

That, if I chance to hold my peace, These stones to praise thee may not cease.

$O$ let thy blessed S A C R I F I C E be mine, And sanctified this A L T A R to be thine.

Sacrifice is the purpose of an altar, especially a classical altar. The words in capitals naturally draw the reader's eye: ALTAR, HEART, and SACRIFICE. The association between the emphasized words and the altar shape suggests that the heart is involved in the sacrifice. ${ }^{15}$ Hence, sacrifice implicates the self both in the capitalized words and the visual appearance of the poem. With these associations invoked by viewing the poem, the reader makes assumptions about the content of the poem as duplicating the complete, crafted structure. However, the poem begins with "a broken altar" (1. 1) despite a complete altar on the page. ${ }^{16}$ Strier's reading of the poem reconciles this seeming disjunction by seeing the broken altar as an internal representation of Herbert's sincere claim "that he has not attempted to tamper with his religious emotions." ${ }^{17}$ Hence, God's altar in the heart and the poet's altar on the page are separate, and for Strier, Herbert turns away from the perfect altar of the poem to God.

The double structures Strier identifies support my argument that the entire poem instantiates a convergence of doubles manifested by the poet's active pursuit of usefulness and the passive state of being use-full, shaped by God. In this opening line, those double structures emerge apparently in conflict with each other. The perfect altar on the page seems to be in tension with the broken altar, adumbrating either the poet's or God's victory. Nevertheless, the emphasis upon the poet as "servant" and the state of emotional vulnerability undermines the assumption that there is a direct conflict here. Instead, the typographical structure on the page complements the broken altar. The altar that the poet rears differ from that "thy hand did frame" (1. 4). Christina Malcolmson states that "the spectacle of poetic labour is paradoxical" because the poem is highly crafted, certainly not unhewn. ${ }^{18}$ She distinguishes between types of approved work, since "the temple of God requires craftsmanship." 19 While I will more directly address the issue of work later, it is essential to note that poetic labour seems paradoxical only if we assume we are talking about the same altar. If, as I claim, there are double structures here, then there is no conflict. The middle section of the altar supports this reading by clarifying the structure of the heart-altar framed by God. As these double structures emerge, they begin to converge, and the double "meets in this frame" (1. 11). "This" has an unclear antecedent and frame provides no real clarification. The frame could be the typographical altar on the page, or it could refer to the bodily frame containing the altar-heart constructed by God in the poet. That ambiguity signals the convergence or meeting of these double structures, one of which refers to the poetic frame and one of which refers to the bodily frame.

The next couplet begins to fill out the structure of the poetic altar and continues the convergence. If the poet holds his peace, his work (the poem) will actively continue to testify to the grace of God who cut the poet's heart. However, the silent poet also praises God's grace by merely existing in the state of being use-full, having his heart worked upon by God. The final couplet fully lines up the double structures to the point that the ongoing works of the poet and his passive status as used by God synch up perfectly. The sacrifice of God becomes part of the poet through God's grace. The actively constructed work of poetic praise (the typographical altar on the page) and the poet's altar-heart also become God's through the experience of becoming use-full. The self in this poem does not dissolve or subversively struggle against God. Instead, this "articulate[s] a feeling of being intertwined with God, but not necessarily, certainly not inevitably, subordinated to him." ${ }^{20}$ The self that we see in this moment of convergence experiences a view of what it looks like to inhabit the paradoxical state of Christ in being wholly used and simultaneously actively useful. This moment prefigures an ideal experience that is always already lost at the moment of realization. Herbert maintains the position and text of "The Altar" throughout the Williams and Bodleian manuscripts. While other structural reasons contribute to this positioning, perhaps the clarity of this experience serves as a model for other moments when he struggles to reapproximate this perspective.

An essential part of the experience of being use-full in "The Altar" is the status of the heart, stony but entirely cemented by God. The stony heart carries many associations. Rosamond Tuve notes that the soul in this poem is "the sepulchrum in which the body of Christ is placed and thus His tabernacle; and the heart of flesh that is 
the Table of Stone whereon the new Law, of love, is inscribed." ${ }^{21}$ The stony heart, usually associated with sin resisting Christ's love, ${ }^{22}$ also figures in Herbert's poem "Sepulchre." "Sepulchre" is not in the Williams manuscript, meaning it was added (though not necessarily written) at a later date. This revision of the corpus as a whole privilege the status of the heart in this poem, particularly as it relates to "The Altar." In this poem, Herbert writes about the body of Christ and the difference between the "pure rock" (1. 10) of the grave that held the body and the "hard hearts" (1. 13) of humanity who tried to stone - both attack with rocks and force out of their hard hearts - and then "falsely did arraign thee" (1. 14). The hardcore here takes up both conceits identified by Tuve. It is a crypt for Christ, but it is also a site for God to engrave upon. The fifth stanza addresses this point:

And as of old the Law by heav'nly art

Was writ in stone; so thou, which also art

The letter of the Word, find' st no fit heart

1. To hold thee. (11. 17-20)

The a, a, a, b rhyme scheme does not require the repetition of art. Still, that repetition combined with the "heart" rhyme reinforces the connection between crafted art and the heart set up in "The Altar" while also emphasizing the poet's amazement that God writes upon the heart despite the heart's imperfect, resistant status and inability to contain God. The engraving of the Law onto the stony heart simultaneously makes the sinful heart the site of use by God. It also suggestively alludes to the arising useful "art" as a result of God's grace. Ironically, the very stony substance of the sinful heart is the best substance for God to construct with or engrave upon. ${ }^{23}$

The paradox of the flawed stony heart as the perfect substance for God to work with and upon - to make usefull - infuses "The Churchfloore" as well. This poem is also not included in the Williams manuscript, suggesting that Herbert's work with the status, shape, and changes of the heart preoccupied his writing from the original compilation, perhaps a result of the experience in "The Altar." "The Church-floor," as critics have agreed, is "a description of the internalized church God builds within the individual heart." ${ }^{24}$ The poem recounts the "square \& speckled stone" (1. 1), "sweet cement" (1. 10), and other material stony substances that represent the floor of the church. I want to focus on the last couplet further to clarify the rough structure of the metaphorical heart: "Blest is the Architect, whose art / Could build so strong in a weak heart" (11. 19-20). Again, the rhyme art/heart reinforces the connection made in both "The Altar" and "Sepulchre" concerning the relationship between actively useful artwork and the passive state of the soul being fully used by God. While the metaphor of a stony church floor standing in for a mushy, weak heart seems inexact, that correlation highlights the ambiguous state of the rough, resistant, broken heart as the perfect building material for God to use. The Architect's job is to build, and He makes a church within the human Spirit, composed of a metaphorically stony substance paradoxically suited to a church building because of the very characteristics that label that heart as flawed or sinful. Herbert's point is that in the self's imperfect state, the heart is still a site for God to work upon, a place in which God can fill the person with use and, as a result, inspire a lesser form of the art that God works.

\section{THE PLACE OF POETRY}

In "Gratefulness," Herbert asks for "such a heart, whose pulse may be / Thy praise" (11. 31-32). The fantasy here is of a heart that praises God in the natural process that maintains existence. Of course, the temporal experience of sin and affliction interfere with that fantasy. Still, for Herbert, poetry as praise is intricately tied to the desire to be so thoroughly used by God that useful works of praise naturally arise. For Herbert, the place for poetry is in the ongoing work of the use-full heart. The problematic negotiation of the changing heart or self requires ongoing analysis of the place and effect of poetry. Is it praising and pleasing God, as Luther says works should, or is it aggrandizing the self and distracting from God's grace? Given the unstable ground of shifting perspective, Herbert's poems about poetry are one of the significant groups he revises and adds to overtime. ${ }^{25}$ As we will see, the moments where he turns to God for assistance are moments wherein Herbert marks the limit of active works to be useful as praise to God. The anxiety surrounding these limit moments requires constant self-analysis to determine the motive and condition of the heart.

If we want to examine the role of poetry for Herbert, it seems logical to begin with the poem he entitled "Poetry" in the Williams manuscript. In the Bodleian manuscript, Herbert changed this title to "The Quidditie." He also changed the order, moving "Poetry" from preceding "Affliction" (I) to "The Quidditie" preceding "Humility." This change in order suggests that whatever the quiddity of poetry is, it may be better suited to the state of humility than to pain. Anna Nardo explains that "a quiddity is both a trifling subtlety and the essence of a thing." ${ }^{26}$ By revising the Name, Herbert simultaneously identifies the trifling work of poetry while defining the substance of poetry. The last two lines accomplish both of these purposes: "But it is 
that which while I use / I am with thee, and most take all" (11. 11-12). Lull claims that "this definition privileges the composing process over the product, implying that revising was a devotional act for Herbert." ${ }^{27}$ While Lull does not directly tie the composting process to what is happening in these lines, her point about revision is vital in light of the revision of the title. In these last lines, Herbert directly connects poetry to God, but that connection depends upon his use of poetry, not upon the inherent nature of poetry. Instead, the 'trifling subtlety' of poetry is that it matters only concerning its use for Herbert in connecting him to God. The use-value of poetry depends upon how much it enables the heart to be more useful and more connected to God; as Targoff says about this poem, "For Herbert, there was no obvious distinction between writing a poem and speaking to God." ${ }^{28}$ By defining poetry as a tool to be used, Herbert both highly values and limits the centrality of poetry in terms of his worship.

In "Life," Herbert elaborates upon the usefulness of poetry and draws upon the common association of posy as meaning both poem and flower. This poem is not in the Williams manuscript, meaning that Herbert added (though not necessarily wrote) it later. This revision to the original collection enhances the link between human life and the productive use of that life to praise God. In the first stanza, Herbert introduces these terms while also marking their mutability:

I made a posie, while the day ran by:

Here will I smell my remnant out, and tie My life within this band.

But Time did becken to the flowers, and they

By noon most cunningly did steal away,

Moreover, wither'd in my hand. (11. 1-6)

The band within which the poet's life is tied refers to the posy, directly associated with flowers inline-four as well as the poem itself, which is a band with the interlocking rhyme structure of $a, a, b, c, c, b$. In this first stanza especially, though, the a rhymes look very much like the $\mathrm{c}$ rhymes, even further emphasizing the interlocking structure. The choice of the Word cunningly invokes the Craftsman (God) in "The Altar" and, by implication, the lesser craftsman of the poet himself. However, the poet's posies wither in his hand; both the flowers held by the hand and the verses written by the hand eventually lose their use-value, fading and ending. Unlike other early modern poets obsessed with eternizing themselves, their beloved, or their poetic skill, Herbert limits the power of poetry.

In the next stanza, Herbert conflates hand, heart, and posy in the first line: "My hand was next to them, and then my heart" (1. 7). This conflation not only makes his "minde to smell my fatall day," (1. 11) but also suggests that there is a limit to the active usefulness of the heart directing the writing hand and the written verse. The third stanza, with its positively connotative adjectives and adverbs "deare" and "sweetly" (1. 13) indicates that the poet accepts and welcomes his use-value. If he is as "fit" (1. 14) as the flowers at making a pleasant smell or ornament, then he is "without complaints or grief" (1. 16). The lesser powers of the hand allude to "The Altar" and the imitation of God's shaping hand in framing the poetic altar, as does the emphasis upon scent in "Life," which suggests the pleasing odours of sacrifice to God. By conflating posy as poem and flower with the heart and the writing hand, Herbert implies that the function of the budding human soul and the flowering verse from that heart is to praise God, to imitate the useful crafting work of God. By combining "The Quidditie" with "Life," we see Herbert's paradigm of poetry as primarily a tool for the heart to use in praising God.

Herbert's "A Wreath" further correlates posy, both as flower and poem, with praise. In this poem, Herbert weaves "A wreathed garland of deserved praise" (1. 1). This poem replaces "Perseverance" in the Bodleian manuscript, and Elizabeth Clarke sees it as "far more positive," which she uses as proof to claim that "the original sequence in the $\mathrm{W}$ manuscript represents Christian authorship in far more problematic terms." 29 While the dynamics of authorship may shift in the Bodleian manuscript, I argue that this revision reflects the same ideas in "Life" concerning the role of poetry as a useful instrument for praise. Judy Kronenfeld claims that in the poem "Herbert will indeed show the inferiority of wreaths, even poetic ones, and their difference from the superior crown ultimately conferred by God." ${ }^{30}$ However, Herbert's offer of praise in the poem is sincere, so the point is not whether his "poor wreath" (1. 12) is as good as God's, but that his offer comes from a sincere heart. Paradoxically, because of the poet and poem's imperfection, the product and poet are useful to God due to the dispensation of grace. Of course, garlands are often made of flowers, and that allusion to the posy - both flower and poem - furthers the portrayal of poetry as a useful means for the heart to praise God..$^{31}$

At this point, however, Herbert's anxiety about the place of poetry remains mostly submerged. In "Jordan" (II) that anxiety derives from an unclear line between praise and self-promotion, a border that tantalizing suggests to Herbert the worldly pleasures of placing poetic art before God. In this poem, Herbert gives voice to that anxiety and draws upon his image of God's voice as a friend to aid him 
in maintaining the place of poetry as a useful tool for the use-full heart. However, critical views of "Jordan" (II) have most often focused on the ending as problematically smothering or obliterating the self and requiring an end to or firm condemnation of creative verse. Only by pairing "Jordan" (II) with "A true Hymne" does the ending make sense within the scheme of poetry as a useful act of praise that necessarily limits the range of poetic power when it threatens to subvert the useful work from a means to praise God to an end in itself.

Originally entitled "Invention" in the Williams manuscript, the revision of "Jordan" (II) changed both its Name and place. "Invention" came between "Obedience" and "Perfection" (which later became "The Elixir"). "Jordan" (II) is placed between "Miserie" and "Prayer" (II). The order alone suggests that the potential perversion of useful poetic work in the combination of "Invention" and "Perfection" is mitigated by placing "Jordan" (II) in the context of suffering and prayer. The name change also significantly shifts the connotation. Tuve explains the seventeenth-century meaning of the Word invention "as that which the imagination uncovers, finds, in the poet's search for a mode of bodying for the unbodied conception of his mind." ${ }^{32}$ She continues by pointing out that the title "Invention" maybe "misconstrued as a sentimental injunction to attend to his simple feelings." ${ }^{33}$ While the feelings in the first two stanzas relating to the joy of creating curling metaphors, decked sense, and clothing for the sun/Son do not seem at all simple, Tuve's point about the potential for the subject to be misconstrued is essential. The very intensity of the first two stanzas in the description of the writing and revision process ("I often blotted what I had begun" 1. 9) seems to merit Gallagher's label of "selfindulgence." ${ }^{34}$ Lewalski sees these stanzas as succumbing to "a 'law of works' in poetry . . . Nevertheless, he then discovers that such 'works' have no merit because of his corruption." 35 These readings seem logical when considering the final stanza in a vacuum:

As flames do work and winde, when they ascend, So did I weave my self into the sense. Nevertheless, while I bustled, I might heare a friend Whisper, How vast is all this long pretence!

There is in love a sweetness readie penn'd:

Copie out onely that, and save expense. (11. 13-18)

The winding flames, like the scent of the flowers in "Life", imply sacrifice, and apparently, this sacrifice is tainted by the poet's bustling. These lines indict the poetic work in the first two stanzas, but the final lines radically shift the tone.

It is the poet's choice to hear his friend. This is not the Lord of "The Altar," and there is no forced compliance. Instead, the friend whispers. The poet presents the friend's words as advice that the poet can choose to listen to rather than a command. These points undermine the critical conclusions concerning the loss of self.

Further, the continued writing of the poem mitigates the conclusion that creative work must be subordinated to copying someone else's (God's) words. Instead, the ready penn'd sweetness relates to the use of the heart by God. For Herbert, in the presence and experience of grace, poetry rightly occupies the place of praise, but expending oneself on art for art's sake distorts its usefulness. ${ }^{36}$

My reading of the end of "Jordan" (II) depends upon pairing it with "A true Hymne." "A true Hymne" is not in the Williams manuscript, so the addition of this poem marks a revision for Herbert, a different perspective on the place and usefulness of poetry that directly informs the revision of "Jordan" (II). Just as Fish (and other critics) read "Jordan" (II) as depicting the dissolution of the self or the subjugation of the abject self to an imposing God, Fish reads "A true Hymne" as beginning with a "debilitating self-concern that . . . is born less of a desire to praise God (who is not mentioned) than of a need to validate the worth of his imagination." ${ }^{37}$ However, Strier points out that the poem is the expression "of the man who has been touched to the heart but cannot attain full or articulate expression," ${ }^{38}$ and that state does not signify a lacking heart or a lacking poet; instead, "the whole point of the poem has been a religious success - God finding an utterance 'fine' - is independent of artistic success." 39 What God supplies is what "the heart wants," 40 assurance that the praise is pleasing even if it begins in the heart as inarticulate meaning.

Herbert the poet supplies all the words of the poem. Just as in "The Altar" with the double structures of the poet's active construction of useful praise and God's structure in the heart, "A true Hymne" represents the convergence of double works by the poet - who writes and finishes the poem himself even if he imagines God supplying the final Word - and God who works upon the poet's heart to reassure him that he is the subject of God's love. With these thoughts about "A true Hymne," the ending of "Jordan" (II) becomes, as previously stated, about the right kind of praise, the proper place of poetry as a useful tool for the poet who seeks to imitate the God who has made his helpful heart. Through the combination of the Spirit used by God's grace and the tool of poetry as an instrument for the poet to praise God, the contours are clearer of what it means to say that good works arise from a state of grace. However, without a more direct examination of what work means for Herbert and how actions benefit others, his poetry seems disconnected from Luther's view of publicly 
beneficial practices that "sincerely and freely serve others." 41

To ensure a high-quality product, diagrams and lettering MUST be either computer-drafted or drawn using India ink.

\section{THE ROLE OF WORK}

In The Living Temple Fish identifies what he sees as a contradiction concerning works in Herbert's poetry: "there is any number of formulas that will allow us to talk about Herbert's poetry, but each of them is a rewriting of the contradiction that exists at its heart, the contradiction between the injunction to do work - to catechize, to raise altars, to edify souls, to rear temples, to write poems - and the realization, everywhere insisted upon that the work has been done already." 42 Fish's contradiction appears to problematize any of the work that Herbert does. For Fish, God consumes all Herbert's actions and, eventually, Herbert himself. However, this view of works is certainly not the one embedded in Herbert's poetry. Preferably, Luther's explanation of the types of actions that arise from a regenerate heart includes praise of God, which we have discussed in the previous section, and also works that the use-full heart does in imitation of God's grace. Herbert conceives of the active doing of works that are useful to others as both voluntary and derivative from faith. Hence, Herbert's concern with work is not vexed by the contradiction Fish identifies, but rather, he worries whether his praise is adequate. If revision for Herbert is a holy activity, ${ }^{43}$ then his poetic work attains a status similar to the excellent work for others Luther writes about. ${ }^{44}$ Herbert's anxiety over the use and effect of his poetry keeps him revising in search of alignment between his constructed and desired selves.

In his poems on praise and employment, Herbert simultaneously evaluates his work. He expresses anxiety over the usefulness of his labour. "Praise" (I) in the Williams manuscript follows "Repentance" and precedes "Nature." In the Bodleian document, Herbert changes the order so that "Praise" (I) follows "Grace" and precedes "Matins." This reordering places together poems with the prayerful subject matter, suggesting that praise and the labour it entails naturally fit into worship. Herbert's revisions of the text itself emphasize the connotation that recognition is both a useful work and one he desires to do and feels he must do. The poem's accretive structure (each stanza ends with the word "more") points to the ongoing nature of this work; this labour is never done, and the poet asks for more of this work. In the opening lines, he identifies poetry as the best way he can praise God: "To write a verse or two is all the praise, / That I can raise" (ll. 1-2). The revisions in the Bodleian manuscript shift the potentially transgressive tone of verse in the Williams manuscript. In the Williams manuscript, the end of the second stanza reads "if I steal up to the skies, / I will do more" (1l. 7-8), but in the Bodleian, it becomes "if I mount unto the skies." The change from stealing to mounting removes the threat buried in the poet's labour. Just as the revisions in the previous section demonstrate Herbert wrestling to find the proper place for poetry, "Praise" (I) shows him trying to find the appropriate role for his labour.

The changes to the final stanza reaffirm the new perspective Herbert has about work. In Williams manuscript, the poem ends:

$\mathrm{O}$ raise me then: for if a Spider may Spin all $\mathrm{y}^{\mathrm{e}}$ day:

Not flyes, but I shall bee his prey

Who doe no more (11. 17-20).

In the Bodleian manuscript, the poem ends:

$\mathrm{O}$ raise me then! Poore bees that work all day Sting my delay,

Who has work, as well as they,

And much, much more (11. 17-20).

The shift from the predatory spider to the busy, productive bee radically alters the sense of the stanza and the entire poem. ${ }^{45}$ While the danger of being consumed like a fly motivates but threatens to overwhelm the speaker in the original version, the revisions intimate joy and pleasure in the exhalation "O raise me then!" The sympathy with the bees further insinuates a relationship between the busy bees working all day and the poet who feels like he needs the bees to "sting my delay" and help him be similarly productive. Most importantly, the final two lines end on a note of enthusiasm for the usefulness of the poet's work of praise. While the labouring bees provide a model for him to follow, the more significant effect of his work requires his continual effort in rendering praise. Just as the bees have productive work, Herbert has work (poetry) "as well as they." By lining up appreciation, poetry, and a desire to work in this poem, Herbert begins to move his poetry into the sphere of productive works.

In "Employment" (I), Herbert expresses a similar point. He again uses the conceit of bees to symbolize productive labour in contrast to his efforts, which he considers to be lacking. He also returns to the flower/vegetative image in "Employment" (I) and "Employment" (II), a symbol both for the use-full heart and also for good works produced by that heart. Besides changing the order of "Employment" (I) and "Employment" (I), Herbert also significantly revises 
the content to reflect attitudinal shifts similar to those in "Praise" (I). In "Employment" (I), Herbert notes that "All things are busy; only I / Neither bring honey with the bees, / Nor flowres to make that nor the husbandry / To water these" (11. 17-20). The imperfect rhyme of "I" to "husbandry" calls further attention to how the speaker does not fit in with the bees making honey. The speaker does not even bring flowers to aid in the making of honey. Implicit in this line is the same posy as flower and poem pun. With this in mind, the anxiety of the "I" relates to apprehension over the inadequacy of his verses as praise and concern that this work does not have the same beneficial effect as the bees' labour. The first stanza also invokes the flower image and notes a sense of immediacy given the fleeting nature of flowers. In these references, the rejuvenation of the annual is subordinated to the effect of "frosts extremities" (1. 3). Stanza six even replaces the image of the poet and poem as a flower by associating him with "a weed" (1. 22). This distress from the inadequate labour and perversion from flower to weed in the Williams manuscript is followed by request "Lord that I may the Sunnis perfection gaine / Give mee his speed" (11. 23-24). In the Bodleian, these lines become "Lord place me in thy consort; give one strain / To my poor reed" (11. 23-24). The original pun on son invokes the criticism of trying to deck the sun/Son in "Jordan" (II), but at the same Time, the poet asks to be speeded to the state of Son's perfection, which would require death. The tone in the revised Bodleian manuscript, however, is more optimistic, with the poet asking to be more aware of the definite presence of God's grace in his heart, a more excellent feeling of being used by God. For the poet, the strains on his reed manifest that desire. The polyvalent meaning of "give one strain / To my poor reed" simultaneously suggests that strains of poetry/music from the poet's reed prove God's presence while also placing the poet in the role of the reed or plant that is bent down only to be raised and made whole by God.

The confluence of the bee conceit and the plant image also mark the revisions of "Employment" (II). This poem is about the desire to be busy working for God and using poetry not to "trade-in courtesies and wit" (1. 3). In the Williams manuscript version, Herbert laments:

$\mathrm{O}$ that $\mathrm{I}$ had the wing and thigh Of laden Bees;

Then would I mount vp instantly And by degrees

On men dropped blessings as I fly. (11. 21-25)

However, in the Bodleian manuscript version, Herbert presents a fantasy of vegetative productivity:

Oh that I was an Orenge-tree, That busie plant!
Then should I ever laden be,

And never want

Some fruit for him that dressed me. (11. 21-25)

Lull says that this revision to an "organic image expresses a covert tendency to self-promotion hidden in the goal of serving God" because "the orange tree is, in its way, even more, upward-seeking than the bee." 46 However, the prevalence of positive connotations surrounding the productive plant image undermines her reading of the plant image as threatening and potentially transgressive. Lewalski points out the biblical basis for the comparison of the speaker to a "plant or tree, expected to flower or to bring forth fruits and be ever responsive to the rains, dews, sunshine, or tempests sent from heaven as well as to the cultivation of the divine gardener." ${ }^{47}$ Like Lewalski, I read the shift away from the bee as a symbol for the self to the tree as a movement to an image of productivity and rejuvenation that Herbert uses consistently throughout his poems. The shift in metaphors also redefines what "employment" is; rather than public service represented by the bees, Herbert identifies proper employment as divine praise of God. In the "Employment" poems, the role of work is modified so that the poet desires and strives to participate in the actual production of useful works because of the inner state of the heart, which desires to praise and labour as do the bees and plants. The role of work here, poetic or otherwise, is to glorify God and benefit others, but the anxiety about whether imaginative work is enough returns when Herbert ruminates on the way to merge creative work with preaching.

Together, "The Windows" and "Praise" (III) construct a picture of the convergence of poetry and preaching as works from the use-full heart of the poet/preacher endowed with grace. These poems, both added in the Bodleian manuscript, mark a moment wherein Herbert's dual roles as poet and preacher merge, complementing each other and producing works more useful as both praise and service. "Praise" (III) begins with the commitment of the "busie heart" (1. 3) to "mean and speak thy praise" (1. 1). The following stanzas recount evidence for this commitment and acts of God's grace. Of these things "and more" (as in "Praise" [I], each stanza ends with "more" to suggest the accretive effect of verses praising God) the poet says he will "sing" (1. 37). He hopes that he "might some other hearts convert" (1. 39). Those hearts will not only experience what it means to be fully used by God's grace, but they will also, in turn, produce useful praise of God. By connecting poetry and conversion, Herbert frames the subject of "The Windows," wherein he meditates upon preaching. 
While many critics have debated Herbert's view about stained glass in "The Windows," there is less discussion about the "holy Preachers" (1. 8). The "glorious and transcendent place" of the preacher is "To be a window, through thy grace" (11. 4-5). Schoenfeldt reads these lines as necessitating "absolute subordination to allow God's light and life to show through." ${ }^{48}$ However, as Strier points out, the preacher does not say "through which thy grace shines" but that through God's grace, the preacher becomes a window. ${ }^{49}$ Instead of the preacher having to completely subordinate the self to make himself a proper window for God's grace to shine through (an impossible task), God's grace transforms the preacher who is "flawed, broken, and fragile" into a window. ${ }^{50}$ Just as the flaws of the stony heart paradoxically make it ideally suited to the work of God's grace to create a use-full heart, the flawed preacher, through God's grace, becomes the perfect vessel in which God can anneal His story. The merging of preaching with poetry in the heart blessed with blessing "bring / A strong regard and aw" (11. 12-13). While the anxiety about the proper place of poetry and the appropriate role of work continues to vex Herbert's poems, "The Windows" in particular is an exemplary moment of revision.

Targoff claims that Herbert's poetry "intertwines the expression of his inner self with the creation of skilful texts that might be shared by fellow worshippers." 51 By examining the structure of the heart, the place of poetry, and the role of work for Herbert and framing that examination through the lens of the use-full heart seeking to produce useful works, it is possible to agree with Targoff that Herbert's poetry does serve a publicly valuable function. In his ongoing efforts to revise after experiences of introspective struggles to analyze the heart, Herbert labours to produce the best works he can. Herbert's concern with "use alone" ("The Church-porch," 1. 155) drives his process of revision, and this same concern also marks his poetic method. According to Herbert, poetry should praise and serve. He connects imaginative production to good works by limiting the power of poetry and its function to a mechanism of prayer. Herbert's inventive method fundamentally emphasizes poetry as a means, not an end, a tool for a labourer to use to "find him, who a sermon flies."

\section{CONCLUSION}

To sum up, it is possible to argue that Herbert was anxious regarding the aspect of shaping the best self. Herbert's poetry intertwines the expression of his inner self with the creation of skilled text, and fellow worshippers might share it. On having examined the structure of the heart and framing examination, it seems he has produced useful work bu employing apt poetic instrument. So his poetry is a means not an end. It is a tool for labourers to apply for searching the Ancient of Days.

\section{ACKNOWLEDGEMENTS}

An acknowledgement section may be presented after the conclusion if desired.

\section{REFERENCES}

[1] George Herbert: The Complete English Works, ed. Ann Pasternak Slater (New York: Everyman's Library, 1995), p. 380.

[2] All Herbert quotations come from The Works of George Herbert, ed. F.E. Hutchinson (1941; corr. rpt. Oxford: Clarendon Press, 1945) and will be cited by line number in the text of my essay.

[3] I, of course, recognize that this Word would not be available toHerbert. Still, I find it a helpful term for modern readers of his text to think about the relationship between being used and users simultaneously. Margaret Turnbull, in "Herbert, Coleridge, Hopkins: Usefulness," George Herbert Journal 31 , no. 1 and 2 (fall 2007/spring 2008): 83-111, focuses on the relationship between being useful and useless, with a particular emphasis on Herbert's "Employment." She notes the distinction "between the uselessness that is and the usefulness that might be" and connects this to "Christ's situation on the cross" (p. 87). While her approach is similar to mine in terms of focus, she does not consider revision as part of the process or the paradoxical convergence of usefulness and uselessness in Herbert poetry. However, her reading of "Employment" and its relationship to Herbert's other poems supplements my argument. See especially pp. 83-89.

[4] While I focus here on Luther, the debate over the role of works certainly not limited to Luther and his followers. It appears in Catholic discourse as well as in discussions between "High Church" Anglicans and those closer to Puritanism. These debates similarly inform my reading of Herbert's poetry. As Christina Malcolmson notes, Herbert had an enduring interest in international Protestantism (Heart-Work: George Herbert and the Protestant Ethic [Stanford: Stanford University Press, 1999], p. 21). This investment in the development of Protestantism certainly included following the debates overworks.

[5] Martin Luther, "Preface to the Romans," in Martin Luther: Selections From His Writings, ed. John Dillenberger (New York: Doubleday, 1962), p. 24.

[6] Diarmaid MacCulloch, The Later Reformation in England, 1547-1603, 2nd ed. (New York: Palgrave, 2001), p. 75.

[7] Diarmaid MacCulloch, The Reformation: A History (New York: Penguin, 2003) further writes about how works do mark the elect: "Good works come naturally to the saved Christian as an expression of love and gratitude for God's 
saving and loving nature, as naturally as it is to be good and loving to the person whom we love passionately" (p. 130). Of course, the question always remains: Are these works naturally arising or am I forcing them to make it seem like I'm saved when I'm not sure if I am? The concern with the quality of good works and the necessity to engage in ethical practices while directing the praise to God is a $\mathrm{v}$ Richard Strier, Love Known: Theology and Experience in George Herbert's Poetry (Chicago: University of Chicago Press, 1983), p. 144.

[8] Richard Strier, Love Known: Theology and Experience in George Herbert's Poetry (Chicago: University of Chicago Press, 1983), p. 144.

[9] Strier, Love Known, p. 99.

[10] Martin Luther, "A Commentary on St. Paul's Epistle to the Galatians,1531," in Martin Luther: Selections From His Writings, ed. John Dillenberger (New York: Doubleday, 1962), p. 101.

[11] Stanley E. Fish, The Living Temple: George Herbert and Catechizing, (Berkley: University of California Press, 1978), p. 490.

[12] Barbara Kiefer Lewalski, Protestant Poetics and the Seventeenth-Century Religious Lyric (Princeton: Princeton University Press, 1984), p. 312.

[13] Michael C. Schoenfeldt, Prayer and Power: George Herbert and Renaissance Courtship (Chicago: University of Chicago Press, 1991), p. 164.

[14] Strier, Love Known, p. 192. See also Martin Elsky, "George Herbert's Pattern Poems and the Materiality of Language: A New Approach to Renaissance Hieroglyphics," English Literary History 50, no. 2 (1983): 245-60. He notes that this is the shape of a Hebrew altar. He uses this shape to refer "to the Psalmic concept of the heart as the true altar" (p. 256).

[15] Robert Shaw, The Call of God: The Theme of Vocation in the Poetry of Donne and Herbert (Cambridge: Cowley Publications, 1981), first observed that the poem appears to be a capital "I" (p. 104). This observation merely gives voice to another connection between the self - I - and the heart

[16] Anthony Low, Love's Architecture: Devotional Modes in SeventeenthCentury English Poetry (New York: NYU Press, 1978), notes the disjunction between the apparently "finished, perfect and symmetrical" altar on the page and that described in the words of the poem (p. 93).

[17] Strier, Love Known, p. 193. See also Rami Targoff, Common Prayer: The Language of Public Devotion in Early Modern England (Chicago: University of Chicago Press, 2001), who claims that "the difference between the two altars neatly corresponds to the distinction between unskillful and eloquent devotion as it was repeatedly formulated in the early modern church. On the one hand, Herbert offers the equivalent of wordless sighs and groans; on the other hand, he proposes a formalized prayer composed in the shape of an altar" (p. 101). I see the distinction Targoff makes between the two altars as similar to the one I make between the structures of actively useful work by the poet and the state of making use-full by God.

[18] Malcolmson, Heart-Work, p. 84.
[19] Malcolmson, Heart-Work, p. 85.

[20] Susannah Mintz, "Unstrung Conversations: Herbert's Negotiations with God," Philological Quarterly 77, no. 1 (1998): 41-71.

[21] Rosamond Tuve, A Reading of George Herbert (1952; Chicago: University of Chicago Press, 1952), pp. 182-83.

[22] See Mary Paynter, "'Sinne and Love': Thematic Patterns in GeorgeHerbert's Lyrics," The Yearbook of English Studies 3 (1973): 85-93. See p. 88.

[23] Jeanne Clayton Hunter, "George Herbert and Puritan Piety," The Journal of Religion 68, no. 2 (1988): 226-41. Hunter points out the similarity between Herbert's view of the stony heart as a sacrifice and site for God to work and Puritan writing. Quoting a Puritan minister, she explains, "When 'the heart is humbled and broken, and contrite,' says Preston, 'it is an acceptable sacrifice to the Lord, which winners it at his hands: he smells a sweet savour from such a sacrifice above all other'" (p. 237).

[24] Gene Edward Veith, Reformation Spirituality: The Religion of George Herbert (London: Associated University Press, 1985), p. 103. Both Veith and Strier agree that Herbert is not talking about a physical church and that the metaphor of the church aids in thinking about the self's relation to God.

[25] Many critics, including Lewalski, see Herbert's poems as cooperative efforts wherein Herbert can "depend upon God to supply the substance of the praises" because, as Daniel Rubey notes, "The Poet and the Christian Community: Herbert's Affliction Poems and the Structure of The Temple," Studies in English Literature, 1500-1900 20, no. 1 (1980): 105-23, the poems "are jointly written contracts with God" (p. 122). I find this cooperative perspective interesting, but I focus on the moments of the breakdown in this imagined collaborative enterprise.

[26] Anna Nardo, "George Herbert Pulling for Prime," South Central Review 3, no. 4 (1986): 28-42. See p. 36.

[27] Janis Lull, "Expanding 'The Poem Itself': Reading George Herbert's Revisions," Studies in English Literature, 15001900 27, no. 1 (1987): 71-87.

[28] See p. 77.

[29] Targoff, Common Prayer, p. 100.

[30] Elizabeth Clarke, Theory and Theology in George Herbert's Poetry: "Divinity, and Posie, Met" (Oxford: Clarendon Press, 1997), p. 277. For a more pessimistic reading of this poem, see Gallagher, "Rhetoric, Style, and George," who says that "A Wreath" is an example of one of Herbert's many performative contradictions because "it is a prayer for simplicity and at the same time a poem of intricate workmanship" (p. 506). While I will discuss the simplicity issue in more detail concerning "Jordan" (I), the contrast in views about the tone of this poem is remarkable to note here.

[31] Judy Kronenfeld, "Herbert's 'A Wreath' and Devotional Aesthetics: Imperfect Efforts Redeemed by Grace," English Literary History 48, no. 2 (1981):

[32] 290-309. See p. 294.

[33] Roberta Albrecht, "Herbert's 'Denial,' 'Jordan I and II,' and 'A Wreath,"' 
[34] The Explicator 60, no. 3 (2002): 127-31. Albrecht says that "Herbert offers his God a wreath that will never wilt," but he also claims that the poem fixes the previous sins of pride in other verses (p. 130). While my point about the garland of posy (poem and flower) relates to Albrecht's formulation of Herbert's wreath, I disagree with his diagnostic approach to lyrics as good or bad. Instead, I see all of Herbet's poems as inhabiting a perspective that shifts with re-vision and enables the poet and his poetry to be more useful at some points than others.

[35] Tuve, A Reading of George Herbert, p. 188.

[36] Tuve, A Reading of George Herbert, p. 189.

[37] Michael Gallagher, "Rhetoric, Style, and George Herbert," English Literary History 37, no. 4 (1970): 495-516. See p. 507.

[38] Lewalski, Protestant Poetics, pp. 314-15.

[39] Margaret Oakes, " 'To be thy praise, / And be my salvation': TheDouble Function of Praise in The Temple," Texas Studies in Literature and Language 47, no. 2 (2005): 120-39. Oakes similarly points out "God does not need to lecture the poet to remind him of what he should be doing, and He does not condemn poetic activity. At the end of the poem, the poet is still writing away, satisfying the important role of being the channel of God's love through His own words" (p. 126).

[40] Stanley E. Fish, "Letting Go: The Reader in Herbert's Poetry," English Literary History 37, no. 4 (1970): 475-94. See p. 483.

[41] Strier, Love Known, p. 201.

[42] Strier, Love Known, p. 204.

[43] Strier, Love Known, p. 205. See also Oakes who says that God supplies the confidence that the poet "is correctly carrying out his charge" (p. 127).

[44] Martin Luther, "The Freedom of a Christian," in Martin Luther: Selections From His Writings, 42-85, ed. John Dillenberger (New York:

[45] Doubleday, 1962), p. 73.

[46] Fish, The Living Temple, p. 169.

[47] Lull, "Expanding the 'Poem Itself,'" p. 79.

[48] Eric Song, "Anamorphosis and the Religious Subject of GeorgeHerbert's 'Coloss. 3.3,'" Studies in English Literature 47, no. 1 (2007): 107-21. Song argues that Herbert's poetry can enact "a religious experience that transcends the individual reader's spatial and temporal limitations" (p. 108). While I agree that Herbert's poetry has this use-value, Song does not account for revision as both an act of devotion and a process for creating a more useful work, which limits the impact of the religious experience.

[49] While I read this change as part of Herbert's process of revision, he is also reworking the classical and quite wellknown contrast of the spider and the bee and their distinctive manner of "working."

[50] Janis Lull, The Poem in Time: Reading George Herbert's Revisions of The Church (Cranbury, NJ: Associated University Presses, 1990), p. 40.

[51] Lewalski, Protestant Poetics, p. 307. See also Frances Malpezzi, "Herbert's 'Grace,"' Explicator 62, no. 1 (2003): 79. Malpezzi writes about the "Hortus conclusus" metaphor that "suggests the paradise might be regained when the garden is touched by the power of the spirit" (p. 9).

[52] Schoenfeldt, Prayer and Power, p. 180.

[53] Strier, Love Known, p. 102.

[54] Strier, Love Known, p. 101.

[55] Targoff, Common Prayer, p. 88. 